doi: 10.15584/tik.spec.eng.2020.9

\title{
Literary Narratives on Collections
}

\author{
Ewa Skorupa \\ Jagiellonian University in Kraków, Poland \\ ORCID: 0000-0001-8645-1977
}

\begin{abstract}
The article deals with collections and collecting as a literary theme. Research on this issue should be undertaken by literary scholars, as collections support the features of literary characters and give protagonists their identity. The work analysed from this angle is Money by Andrzej Strug from 1914. It interprets and describes three different collections and three different collectors: the eccentric Lyttons and their museum of stones, Lucy Slazenger's precious jewellery collection and the art collection of Osias Murway, an enthusiast of antiquities.
\end{abstract}

Keywords: Andrzej Strug, loneliness, collecting, domination, power, museum of stones, tragedy, melancholy, a collection of jewellery, artwork, suicide

\section{Research perspectives}

Collecting, according to Walter Benjamin, ennobles objects as a collector deprives them of the stigma of usefulness; instead, each specimen becomes something unique, acquires an artistic, cognitive and aesthetic value, ${ }^{1}$ sometimes also a symbolic one. Collections help with manifesting and determining the identity of their owner, also their social and material status. In other words, as specified by Krzysztof Pomian, collections "allow revealing cognitive and aesthetic attitudes, intellectual practices, social relations, images. As intermediaries between the invisible and the visible, objects, being a part of a collection, are surrounded by an aura of sacrum....".

Research into collecting done by historians of art, science, religion, by bibliologists, museologists, who described the vicissitudes of various collections, their content, collectors' profile, their predilections, today has been

${ }^{1}$ See: R. Tańczuk, Ars colligendi. Kolekcjonowanie jako forma aktywności kulturalnej, Wrocław: Wydawnictwo Uniwersytetu Wrocławskiego, 2011, p. 9.

${ }^{2}$ K. Pomian, "Słowo wstępne," in: Nowoczesność kolekcji, scientific edition by T.F. de Rosset, A. Kluczewska-Wójcik, K. Lewandowska, Toruń: Wydawnictwo Naukowe Uniwersytetu Mikołaja Kopernika, Centrum Sztuki Współczesnej “Znaki Czasu,” 2010, p. 9. All the quotations from the Polish sources have been translated by Łukasz Barciński, unless stated otherwise. 
complemented significantly from sociological, anthropological, aesthetic, psychological and philosophical perspectives. This interdisciplinary interest has developed a new direction of studies on collecting - collecting studies which aims at the explanation of the phenomenon of collecting, at bringing "attention 'to the cultural process rather than to the history of culture."” However, the field of literary research remains unexplored, i.e. one which as its subject of studies should have minor and major narratives dedicated to the issue of collecting in belles-lettres, the collectors' psychology, the type of expression evoked by a given object from a currently gathered collection in an owner or an observer. Admittedly, there are works that show relationships between an iconic and literary text, thus analysing a painting as seen through the eyes of a poet, ${ }^{4}$ still they are not interpretations that cover within their scope literary narratives about collections, only meditations, reflections, experiences, and a writer's impressions about one creation of an artist-painter; a creation which, additionally, is treated as something unique, not seen as an object included in a bigger collection. Literary works, especially in prose, containing fragments of stories about various works of art, knick-knacks or any other objects consolidated into a collection, gathered by a fictional character, have not yet become the subject of a deeper reflection in literary studies or anthropology. Only the themes of a library and a book aroused researchers' interest, and was elaborated on in e.g. Biblioteka $i$ książki $w$ literaturze, ${ }^{5}$ or signalled in texts scattered in various journals. ${ }^{6}$ A completely new research area emerges; one which for many years will fascinate literary scholars, extrapolating from belles-lettres the motif of a collection, a collector, the activity of collecting etc. Scientists will attempt to find the answer to the question of the functionality of such discourses, ways of fusing them into narratives, forms of experiencing an exhibit in a collection by a fictional character, the question of created mood, colouring, expression and psychology of the act of collection. Whether the presence of

${ }^{3}$ R. Tańczuk, op. cit., p. 11.

${ }^{4}$ See: A. Pilch, Formy wyobraźni. Poeci współcześni przed obrazami wielkich mistrzów, Kraków: Wydawnictwo Uniwersytetu Jagiellońskiego, 2010; E. Skorupa, "Thanatos Malczewskiego i thanatos poetów," in: eadem, Zaulki literatury. Interpretacje tekstów kultury XIX i XX wieku, Kraków: Wydawnictwo Uniwersytetu Jagiellońskiego, 2015, pp. 125-141.

${ }^{5}$ See: Biblioteki i książki $w$ literaturze, edited by K. Bednarska-Ruszajowa, Kraków: Wydawnictwo Uniwersytetu Jagiellońskiego, 1998; K. Bednarska-Ruszajowa, Biblioteki i książki w pamiętnikach polskich XVIII-XX wieku. Rekonesans źródtowy, Kraków: Wydawnictwo Uniwersytetu Jagiellońskiego, 2003.

${ }^{6}$ See: I. Nagórska, “Biblioteka w poezji polskiej," Poradnik Bibliotekarza 1994, No. 10, pp. 15-16; M. Rząsa, Książka w Piśmie świętym i tekstach pisarzy kościelnych, in: Prace młodych bibliotekoznawców, Kraków: Polskie Towarzystwo Bibliologiczne, 1994, pp. 28-37; M. Stolzman, "Wiedza o książce w dziełach literackich," Roczniki Biblioteczne 1988, Vol. 31 (1987), Vol. 1, pp. 219-233; Z. Skibiński, "Motyw księgi w poezji Czesława Miłosza," Mazowieckie Studia Humanistyczne 1996, No. 2, pp. 75-94; M. Garbol, "Motyw Księgi u Brunona Schulza," Teofil 1994, No. 1, pp. 64-72; J. Kałążny, "Motyw biblioteki w literaturze," Biblioteka 1998, No. 2, pp. 5-14. 
the very act of collecting serves the purpose of showing an additional characteristic of a literary character, what kind of collectors' items are particularly willingly described and which create a unique atmosphere - these are just a few research suggestions. Certainly the existence of the motif of collection and a collector in literary works has been heavily influenced by the fashion to collect works of art which, apart from magnates and wealthy landowners, was also popular among well-off city-dwellers.?

It may be assumed that Noah was the first collector, and the biblical story includes some significant threads for collecting: "longing and nostalgia, salvation and loss, desire to establish a lasting and complete system despite the destructive power of time." ${ }^{8}$ This apt observation is an excellent introduction to reflections about the literary motif of collections and collectors. The work selected for the purpose of analysis is Money. A Novel from a Foreign Life by Andrzej Strug from 1914. This intricate story full of dark secrets shows the lives of American billionaires and "luxurious" criminals who have fun in the Old Continent, relaxing in Paris, in fashionable Swiss resorts, finally to come back home on board a transatlantic liner. The depicted world is ruled by wealth, expensive cravings, a drive for acquiring a fortune but also the "whirls" of collecting. No wonder that in this very space, full of glamour and desire for collecting money (or sets of items), all collections require the collectors to lay out enormous financial resources, as the objects or their gathering is expensive: museums of rocks, collections of jewellery and the collection of works of art.

\section{Museum of rocks or collections of natural resources}

The first known collection, which determines "the beginning of collecting perceived as gathering objects not for their utilitarian purposes," is deemed to be a set of stones found in a cave in France that is eighty thousand years old. ${ }^{9}$ Regardless of the motives of collecting at that time, which were apparently different from the modern ones, it is worth asking the question about the function that is performed by collections in the past and today. Is it a way of manifesting the social status of man, a type of investment of capital, or "a source of emotions, aesthetic, ludic pleasures, knowledge,"10 or maybe something else?

The most interesting and probably the most extravagant aspect of the novel is the collector's passion of the Lyttons, father and son, who, as known

${ }^{7}$ See: B. Kowalska, “Kolekcjoner wobec sztuki swoich czasów," in: Nowoczesność kolekcji, p. 17.

${ }^{8}$ The Cultures of Collecting, edited by J. Elsner, R. Cardinal, Cambridge, Massachusetts: Harvard University Press, 1994, p. 1, cited after: R. Tańczuk, op. cit., p. 105.

${ }^{9}$ See: R. Tańczuk, op. cit., p. 105.

${ }^{10}$ See: ibid., p. 107. 
globetrotters, "stricken with the mania of climbing any mountain peaks all over the earth," established a private museum, in which the exhibits were mountain rocks and objects related to mountaineering. Collectors enthusiastically praised the interior, the decor and exhibits of this extraordinary "chamber of curiosities":

A collection one of its kind! You will never see anything like it! [...] Here - a giant hall, covered with two-metre high maps of all the mountains in the world. Higher - arranged in four directions in a panoramic way, plafonds, with the most beautiful mountainous landscapes: the Himalayas, Caucasus, Berner Oberland, Tyrol, the Andes... [...] Between windows our photographs. We take our photographer everywhere, he's a good mountaineer. The library includes everything that has ever been written about mountains, climbs, disasters. A separate cabinet with reports from our travels. We take our secretary everywhere, he's a good mountaineer, who keeps record of the travels. We print everything in trade journals and papers and then publish separately in a limited number of copies. [...] Mountaineering equipment of any kind: ice axes, lines, crampons, staples, hooks - some of them extremely ancient. The ice axe and line of the biggest lover of mountains and mountaineering, Pyrenees climber - Sir Russel. Alpine boots, a keepsake of Baron Wenzl, who died in the famous Jungfrau disaster. And in the glass cabinets... [...] Rocks from mountain peaks, authentic and described by documents, from the highest altitudes of the world. There are more than seven hundred of them... (p. $38-39){ }^{11}$

And precisely these rocks proved the uniqueness of the described museum, especially that their size and resultant weight were the source of many inconveniences for the collectors, with porters also running the risk. A curious fact in this context is the information about the existence of an authentic collection of a French intellectual and writer, Roger Caillois (1913-1978), who collected "a collection of fragments of rocks - more than two thousand semi-precious rocks and minerals - evoking travels made by him and conducted research, in a different way described later in his books." ${ }^{12}$ For Caillois, a rock becomes "a metaphor of sleep," an object of contemplation, inspiration for writers, the equivalent of a metaphysical relationship with the world. He described it, admired it, named it, and adored the intensity of its colour, shine, purity and beauty. It is possible therefore to devote one's whole life to the collection of rocks; however, the difference between the passion of the French writer and the fictional characters from Strug's Money was, among other things, the size of the collected exhibits. And this very size constituted the unique aspect of the American world created in the novel. Rocks from the Frenchman's collection, rock crystals, minerals such as jades, turquoises, lapises, agates and jaspers, usually small, were, on average, from ten to twenty centimetres long, while the Lyttons' stones were gigantic and weighed from nine to thirty kilograms, with porters carrying them with utmost difficulty from mountain tops. During one of many climbs, one porter paid for it with his

${ }^{11}$ All quotations in brackets come from the following publication: A. Strug, Pieniadz. Powieść z obcego życia, Warszawa: "Ignis," 1921.

${ }^{12}$ C. Morando, "Kolekcja Rogera Caillois: pochodzenie kamieni," in: Nowoczesność kolekcji, p. 169. 
life, but the rock, "luckily," according to the expressed collector's opinion, was saved. In this way the creator of the museum unequivocally emphasised their "morbid" devotion for the collection.

The Lyttons, thanks to their activity, transformed the collected items into objects endowed with significance and value. ${ }^{13}$ Previously, the rocks belonged to nature, while collectors, by extracting them from the extra-cultural space, gave them a new meaning. For them, one advantage of things obtained from the natural sphere was the extraordinariness and inaccessibility of the places where there were originally located. By creating a museum, they made the rocks and alpine areas accessible for everyone who wanted to visit their chamber of curiosities. In their passion they desired to gather within a small space a collection of small mountain tops in miniature and to show what previously only chosen ones could see. Probably, because of the majesty, greatness and metaphysicality of mountains, the Lyttons were not satisfied with gathering little rocky slivers which would be entirely sufficient for the audience; instead, they transported boulders of enormous sizes from the most dangerous summits, thus making their objects retain the aura of monumentality, dignity and loftiness, which they had in their original surroundings. Through the enormous size of the collected items the Americans highlighted the grandiosity and gigantism of the mountain, which is how their personal motivation for collecting could be explained.

Some psychologists were scientifically interested in the issue of collecting, e.g. Karl Abraham, Ernest Jones, Otto Fenichel, by referring to Freud, attempted to explain this passion with the controversial theory of eroticism, often abused in its possible interpretations..$^{14}$ Much more convincing are the views of e.g. Krzysztof Pomian, who considered collections from the $16^{\text {th }}$ to $18^{\text {th }}$ centuries to be a tool of "obtaining prestige, publicity," a testimony of "belonging to a specific environment," a mark of "wealth." 15 The $20^{\text {th }}$-century characters in Money by Strug, obsessed with the mania of collecting alpine boulders, are distinctive thanks to their passion: their collections give them identity, they become famous, they establish their material status. However, their milieu does not respect them, does not admire their hobby, and speaks of their fortune instead. The most sophisticated circles are appalled at their extravagance, at the waste of their fortune which could be used for charitable causes; entrepreneurs, dreaming about the Lyttons' wealth, fantasize about their own accomplishments; some of them think that the boulder maniacs are frivolous, some that they are foolish, others that they are not of sound mind. Universally they were the subject of ridicule, laughter and disparagement.

${ }^{13}$ See: R. Tańczuk, op. cit., p. 13.

${ }^{14}$ See: ibid., p. 101.

${ }^{15}$ K. Pomian, "Kolekcjonerstwo i filozofia. Narodziny nowożytnego muzeum," in: idem, Drogi kultury europejskiej. Trzy studia, Warszawa: Wydawnictwo Instytutu Filozofii i Socjologii PAN, 1996, pp. 108-172 and R. Tańczuk, op. cit., p. 114. 
This almost unanimous and public condemnation, was slightly mitigated in the novel by the opinion of two negative characters: Shurman - obsessed with the idée fixe of conquering the world by means of wealth; a man who is a murderer, causing the death of his niece, Jenny; and van Joerg - a paedophile, taking advantage of young girls, a cynical man, poking fun at moral laws with impunity, thanks to his wealth. Both men with shameful lives are indignant at the basically innocent passion of collecting rocks, suspecting the Lyttons of mental illness born out of slothfulness.

Consequently, the museum of nature, in the Lyttons' design, intended to generate admiration, to kindle passion and to evoke respect and recognition for the promoters, was commonly recalculated into money. So perhaps from the perspective of the "sender" or the founder, it played other important roles. For the Lyttons the expensive activity of collecting undoubtedly constituted a manifestation of their social status and wealth but also was a source of satisfaction, pleasant feelings and entertainment: collecting was a way to achieve self-fulfilment.

Researchers focus on the specific function of the atmosphere created by collections. ${ }^{16}$ Even if single objects do not possess a certain aura, they obtain it when placed within a larger collection. This valuable thought can be reflected in the Lyttons' museum, especially since their passion and authentic fervency in completing their collection cannot go unnoticed. Each newly acquired boulder started to play the role of a fetish, a magical object which, transported from the mountains, drew crowds yearning for sensation. The moment when a reddish mountain block from Matterhorn was "greeted" is described in detail. The whole Swiss town of Zermatt "took to the streets" to greet the mountaineers, who descended "in grand style and with parade" to delight the world with the view of a new stone:

In front there were six guides walking in pairs with bundles of lines, with some hooks and other accessories of a strange church service, unknown in the craft of mountaineering. Their hats were decorated with flowers, wide weather-beaten mugs were laughing with delight. Behind them Lytton, the father, and Lytton, the son, strode proudly and with solemnity, bowed to the left and to the right to the audience who were screaming, clapping and waving their hats, rolling on the ground with laughter. The secretary and the photographer of the expedition walked at the end.

Next, six porters carried on their shoulders the stretcher on which, entangled in lines and drowning in the blooming branches of rhododendron, lay the rock from the peak of Matterhorn. The auxiliary porters, and men carrying tents, linen, mobile kitchen, cameras and other bundles bought up the rear.

It is not known how the rock had been imagined, suffice is to say that it looked strangely small to everyone. An irregular lump, fantastically hewn by the eternal forces of winds and frosts, attracted everybody's attention. People were pushing their way from all directions, feeling the cold rock, knocking their sticks, evaluating its weight, walking in the way of the porters, finally stopping the whole procession. (p. 137)

${ }^{16}$ See e.g.: W. Benjamin, "Dzieło sztuki w dobie reprodukcji technicznej" ["The work of art in the age of mechanical reproduction"], translated into Polish J. Sikorski, in: idem, Anioł historii. Eseje, szkice, fragmenty, selection and edition by H. Orłowski, Poznań: Wydawnictwo Poznańskie, 1996, p. 205. 
Waiting for the Lyttons' march, crowds of onlookers with amused faces treated this event as a local sensation, ludic entertainment, a form of public spectacle; it is curiosity that brought them together. The greeting ceremony, which was accompanied by the chanting and cheers of the people gathered, the sounds of alpine horns and applause, was graced by the speech of the senior climber, Cobson, "the priest of millionaires," who in flowery language, with kindness, made fun of the museum of rocks. At the end he decided to make a joke, imperturbably received by the Lyttons: he gave them a moss-covered stone allegedly coming from a volcano on the moon, to complete their collection. Strug, writing this scene, did not suspect that a few decades later, it would be possible to see authentic moon rocks brought by astronauts, and that it would be a profound experience for the observers.

In the few reflections above it can be clearly seen that the relationship of the subject with the object was not uniform. The collectors were distinctive in that they had a passion for gathering and an attachment to every exhibit in the museum; the relationship between the owners and their property was personal, strongly emotional and passionate, while the prospective audience was more focused on watching the collectors than the collections themselves. For the Lyttons the rocks became priceless, while for the crowd they represented an incomprehensible financial investment, a natural curiosity, at most. Observers looked at the rich Americans' mania in a merchant manner, the collection as a set of exhibits does not evoke emotions; instead, they calculated its completion in financial terms. Researchers underline the passionate relationship of a collector with the object, a strong emotional bond of a gatherer with the items in the collection, fanaticism, which is an inseparable part of collecting, and even the feeling of loftiness which accompanies a collector's passion. The Lyttons' collection can be defined as a systematic collection with the important function of categorisation. One of the enthusiasts described it in the following manner:

An immense effort. We have to be present all the time. You cannot rely on people authenticity is what's most important for us! In our collection there is no humbug, as in all the remaining museums. - Each item is accompanied by a golden plate with an inscription and a number. It is a number of a relevant document, executed and certified by the proper authorities with the signatures of the guides, witnesses. - One of a kind... - The biggest curiosity of our Frisco is placed in the guides to our beautiful city... (p. 40).

And what were the psychological factors determining the Lyttons' passion for collecting? The specialist literature on the subject mentions many motives, e.g. "the will to possess, the need for non-standard activity, the need to transcend the boundaries of one's self, the need to classify and systematise objects, ${ }^{{ }_{17}}$ which are accompanied by negative and positive feelings. The former include: excitement related with the search for new elements of the collection, happiness upon obtaining them and the related fulfilment,

${ }^{17}$ P. Cabanne, Wielcy kolekcjonerzy [The Great Collectors], translated into Polish by F. Buhl, Kraków: Wydawnictwo Literackie, cited after: R. Tańczuk, op. cit., p. 249. 
the pleasure of arranging and displaying the collection, satisfaction with the classification of the set. The latter, negative ones pertaining to enthusiastic collectors are as follows: desire for more exhibits, longing for them, anger and sadness in the face of defeat in rivalry with other collectors, fear of losing the collection. ${ }^{18}$ Moreover, the collected objects themselves are a source of joy since they can be looked at and admired. Some collectors experience the feeling of "illusion of control," which is projected from one's own collection onto people and the world (one theory states that the inclination to collect manifests the tendency to dominate and control). But the very activity of collecting, seen as a respectable pursuit, makes the collector feel important, valued and significant in the world. Collecting brings them a feeling of competence and success.

Many of the above psychological factors can be attributed to the fictional characters in Strug's novel. The eccentric Lyttons, to distinguish themselves from their environment, felt the desire for non-standard activity. Obtaining new rock fragments became the meaning of life for them and a challenge. They were excited about alpine expeditions and developed a strong emotional connection with every new rock. Furthermore, they played the role of experts in their field, which gave them a pleasant feeling of importance. Also, they expressed their wealth in a non-standard way.

\section{Jewellery collection of Lucy Slazenger, the copper king's daughter}

Researchers who endeavour to study the relationship between collecting and consuming state that collecting is a specific consumptive activity, and even a type of "pursuit of redundant luxury goods." goods could certainly include the collection of expensive jewellery owned by another interesting character - Lucy Slazenger, the only daughter of the copper king, a man more powerful than monarchs with regard to his wealth. However, Lucy can hardly be categorised as a genuine collector, as jewels accompany her in a natural way; she owned them and did not attach any particular importance to this fact. And as in the case of the "museum of rocks," the ways in which fictional characters experienced "objects of the collection" were diverse. However, the jewellery, a tool for obtaining prestige, was kept in hiding and only occasionally shown to the outside world, although everybody knew about its existence. It was particularly interesting for the "luxury criminal underworld," who wanted to take possession of it.

The beautiful gems highlighted Lucy's biggest personal drama - her ugliness. People talked about her: "unsightly, but very healthy, extremely

${ }^{18}$ See: R. Tańczuk, op. cit., p. 250.

${ }^{19}$ R. Tańczuk, op. cit., p. 101. 
shapely, filthy rich. [...] A dowry incredibly colossal!” (p. 52). She was praised for "the wonderful build" of her body and noble movements. This commonly liked girl, breaking records in many sports, "approachable and nice," an energetic princess of copper, had from time to time attacks of desperation, bordering on madness when feeling the burden of the onlookers' humiliating gaze, as "she experienced the pain of her ugliness." Information about the deficiencies in her appearance come up repeatedly in the novel. The longest fragment reveals the ineffective efforts of medicine made in the attempt to improve the beauty of one of the richest women in the world:

The most famous experts from all over the world worked on her. [...] They made her complexion smooth, wonderful and warm in tone. They lengthened eyelashes, drew the eyebrows, they tormented her poor, thin lips till they acquired a line. [...] Her nose underwent tortures and surgeries. Nothing could give character or expression to the face. She always remained the same - cursed, colourless, stupid and comical - a caricature of a German woman from "Simplicissimus," trivial, fat and boorish. (p. 165-166).

Lucy tried to mitigate her curse by activities that at the time were more popular among men: she drank cognac in large amounts, smoked cigars and played billiards, forced herself to play sports. Still she always knew her worth: she knew that as the only heiress to her father's billions she could have any man as her husband. Aware of her power, she dreamed about the impossible: "to feel on myself at least one delighted, loving look..." (p. 166). The jewels she owned are strictly intertwined with the story of her ugliness and female desire. The pearl necklace consisting of pearls worth four million, labelled as "two hundred wonders of the world" is described in a comprehensive and poetic way:

Strings of the necklace wobbled in a slight pendular movement. Four rows of jewels laboriously collected for years all over the world. Ages have passed since the time they left their native forest at the bottom of the sea. Disseminated in the world, they decorated the beauty of women in the past, fulfilling their eternal vanity. They were desired, purchased for many purses of gold, for the price of blood, ignominy, treason. They were traded for villages and towns along with the fates of the people living in them. They were the reward for faithful wives, payment for sins. Worn by queens. Embellished miraculous paintings in churches of East and West, adorned courtesans. Looted in wars travelled to remote countries, inherited, went from one generation to another, passed through a thief's hands, through a highwayman's bloody hands. Pawned at a Jewish-usurer, plundered by a Christian ruled by edict or by force, going astray (p. 157) in the world in the crowd of mortal people, leaving the deceased and weak, passing to the young and strong. Old, old-fashioned, immemorial seeds. From Cleopatra's Semiramis necklace, from the womb of the dreamlike Helen of Troy. From the triad of rulers who erected the first pyramids, from the Memnon's altar, from the ring of the Chaldean mage-wonderworker. (p. 157-158)

This necklace was placed around the neck of the beautiful Mariette, a lady companion to Lady Hartley. The beauty of the women fused with the beauty of the pearls, which evoked various reactions from onlookers: erotic desire and ecstasy in Ada Hartley and admiration mixed with humiliation and pain in Lucy. The gem-ornamented Mariette derived a sense of masculine power, authority and domination from the necklace. 
Lady Hartley combed her black hair and put her diadem-band on, encrusted with rainbow-bluish pearls. She took a couple of steps back and gasped with admiration. The girl looked like a goddess. A secret charm emanated from her. She was no longer a woman. Masculine pride and masculine power were written on the forehead, bound like in a fairy-tale prince. The girl's chest rose with the languor of delight, temptation and weak-willed devotion. The eyes looked hard, bright and deep, while the lips parted with desire (p. 160).

The scene directly led to a fit of hysteria in Lucy Slazenger who consequently destroyed the pearls, thus metaphorically annihilating beauty: the destruction of something being her opposite, depriving the jewellery of financial, collector's and decorative value. In the case of this collection we are dealing with the opposite to a collector's efforts: instead of cultivating her collection, Lucy devastates it as she is obviously a collector against her will. She possesses what her father treats as a special kind of consumption and investment. Thanks to this collection, serving the function of aesthetic fulfilment for an environment sensitive to beauty (as seen best in the above scene with Mariette), the Slazenger family manifests its wealth and the power of money. It can be said that the "quasi-collection" becomes for the copper king an exclusive tool to flaunt his social status, but also a capital investment, shattered by Lucy in an attack of momentary madness. There is no information about the aesthetic pleasure provided for the owner of the jewellery. Slazenger's daughter usually experiences strong negative emotions evoked by the gems: the beauty of the pearls reminds her of her own ugliness, which is why their beauty is unpleasant, hated and in her opinion, absurd. Pearls that "mock" have to be crushed:

Suddenly, she came across a casket. It was open. The pearls mocked her. Without thinking, she grasped the strings and started to jerk at them with her strong hands. But the pearl strings did not let go. Lucy started to look around the room, searching for something with insane eyes. At last she seized a heavy bronze candlestick and on a marble plate of the console she started to hit and smash the pearls one after another. They faded, died submissively, crumbling into dust. Each blow at a terrifying speed melted down the colossal amount of their value. Four million!... Two million... One million... One hundred thousand... Nothing... Lucy was breathing heavily, with devilish joy. She looked at the crumbs and remains, covering the marble of the console and carpet and laughed freely, with indescribable relief. (p. 168 -169)

However, the collection of jewellery also evokes different emotional states in Lucy. For the very first time she starts to treat her gems as a set of beautiful works of art which can play an artistic role in her life. She wants to fulfil "the quirky fantasies" of her lover who, posing as an artist-painter, wanted to see her showered with expensive jewellery like Salome from Moreau's painting:

Lucy dreamt that she was Cleopatra. [...] Oh, if I were rich... I would dress you from head to toe in jewels... [...] If I could afford it, you would be embellished like Salome in Moreau's paintings... Millions would adorn your head, breasts and hips. On every finger and every toe - rings. Priceless pearls, gigantic diamonds, emeralds, and rubies. Royal diadem on your head. You would be heavy with jewels! Your heavenly body, dressed in splendour... (p. 333).

In fact this "luxury fraudster" and thief is more sensitive to the material value of the jewellery than to its artistic merits. He derives aesthetic 
pleasure from the sight of the jewellery because they mean material wealth. Before Lucy discovers the terrible deception, she prepares herself for the role of Salome from Moreau's painting, which she is supposed to play during the tryst with her lover. From her collection, she chooses the most beautiful objects, which are described in greatest detail in the novel as collector's items:

...she took out jewels from saffian boxes and caskets. She chose and placed on a string several dozen rings and put aside a few gold chains, bracelets and shoulder-straps, all of the necklaces, hair bands. She took a fancy belt, heavily encrusted with huge, well-matched chrysolites, and another one, consisting of gold buckles, set with diamonds. From the earrings she chose only a few big hoops, iridescent with the sparks of diamonds. She had to leave many things, beautiful brooches, pins, which did not match the garment of Salome from Moreau's painting (p. 336).

The final part of the "jewellery" scene reveals the dark secrets of the great deceiver, Juan, and his beautiful companion, whose greed and desire is evoked by jewels. All of the narrative devices concerning the collection of precious valuables support the characterisation of Lucy and other fictional characters. The copper king's daughter starts to appreciate her treasure only after she wants to fulfil her lover's sensual-erotic and artistic fantasies, influenced by the mood of the painting. The comely Mariette for a moment takes control of the power given by the expensive pearls, Lady Hartley in an insane ecstasy stares lustfully at the double beauty: her lady companion and the jewels. Eroticism, passion, feeling of power, greed - these are just some of the emotions evoked by the collection of jewellery in the characters in the novel.

\section{Osias Murway - a collector of works of art and a lover of antiquity}

The final example of collections from the novel are the most "classic", i.e. those admired by the world as a display of valuable works of art, although only a single artefact being a part of them was described in the text. The owner of numerous exhibits was Osias Murway, a commonly known collector of artistic works and a lover of antiquity, who established private museums in Boston, Paris, London and Florence. His passion for obtaining new trophies was admired by some and mocked by others. He was called "a great geek," an expert, "an ardent enthusiast" and lover of beauty, a philosopher, "a propagator of art," a friend of John Ruskin - an English theoretician of art, a famous essayist and a lover of Gothic. His personal features and qualities include an even temper, a comprehensive mind, laboriousness and modesty. Some were amazed at his ascetic lifestyle, which stood in sharp contrast to his great passion; others were fascinated by his joy of life and moral and physical health. 
The collector was introduced to the narrative when he was using a magnifying glass to carefully examine an old picture on yellowed paper, devoid of the artist's signature, which Murway considered to be a work by Dürer. The description of this unknown engraving, the name of which was given by the collector himself, revealed two significant layers of experiencing a work of art. The first, more superficial one, focused on the in-depth analysis of the content of the image, constituting an aesthetic experience for an art lover:

In the paper a man in his prime, deep in his thoughts... [...] Huge, rich rings on his fingers. His garment is spectacular, the chair he is sitting on is intricately carved, so is the old-fashioned table he is leaning on. On the table a heavy, full purse - a few jewels and rings fell from it, so did a chain, a chiselled bottle. In the empty Gothic room only two, elaborately cast chests. Hanging from them there are solid, enormous padlocks with huge keys. Bulging sacks tied with ropes emerge from one chest, from the other - valuables piled up to the very top, ancient riches: candlesticks and encrusted crucifixes sticking out, hangs a necklace with huge stones. Gold cups, jugs, a Gothic refectory with woodcarving ornaments... At the master's feet a huge, fattened dog sleeps blissfully on a patterned cushion (p. 346-47).

The other one, in turn, went deeper, intentionally hidden by the artist "under the banal warp" of reality, was visible only to the audience that attempted to solve the mystery of the work and understand the hidden senses of the artistic message. The contact, limited only to the formal experience of the work, ended with registering its technique, content, lines and perspective, while a spiritual relationship with the work became an endless subjective interpretation, an attempt to penetrate through the psyche of the artist and recognise the interior of the figure represented in the picture:

$\mathrm{He}$ is tormented by a difficult and unsolved matter. For many years the same, considered a hundred times. It hurts, bothers, like an incurable wound. His eyes became weary from continuous staring at the same image, on the forehead, the face furrows were carved, like rutted roads. His countenance was covered with marks, as if fate had inscribed his ultimate sentence with secret letters. Great misery bent down his head, bowed his whole posture. Powerlessly, he leaned his head on his hands in exhaustion and pondered. [...] Tormented are the eyes of a recluse staring at remote worlds, and through ogival window, widely opened, they can see the boundless empty space, flat as a sea. A desert unknown to nature - desperate, cruel. Nothing, limitless, still, dead and monotonous. An image incomprehensible for reason, unbearable for human sight. More terrible than death. (p. 346-247)

For Murway the unknown piece by Dürer - in the above story about the artefact - was also a story about him as a man. He enjoyed a collector's "work," i.e. entering into the catalogue newly acquired works of art, as he treated this activity as the culmination of a laborious pursuit; however, the engraving revealed to him at the same time the sad essence of life. Everything became an illusion for him, and this recurring thought led him to the suicidal leap into the ocean, which shocked everybody around. He himself became the figure from the engraving looking at the endless vastness, lost in the space of the desert. He too, like the painter's figure, plunged himself this time in the depth of the ocean. The plasticity of the two images: the painting and the literary one can be explicitly seen. The suicidal death of Osias was him being devoured by the vastness of nature. 
In the character of Murway, it is possible to discern many important issues for the figure of a collector: genuine expertise concerning works of art, with the relevant qualities of authenticity, antiquity, artistic merit, intricacy of workmanship, then the creation of spiritual culture, the relationship between a collector and the collected set of objects. Strug's character finds aesthetic pleasure in looking at his artefacts, which also become objects of contemplation and searching for the meaning of life; museums, in turn, in the specialist literature on the subject, are treated as a symbol of power and social status, bringing personal satisfaction to Murway. One important condition of the existence of a collection and one of the goals of a collector's activity is achieved in this case: making the collection public, by presenting it. The experiencing of masterpieces had its tragic consequences and, to a greater extent than in any other case, it served the function of a biographical object.

Narratives about collections introduced into the novel by Strug facilitate the characterisation of literary characters; sometimes their portrayal is possible thanks to the depiction of the passion for collecting. In other words, collections endow characters with identity: the Lyttons without their museum of rocks do not exist, their presence in the world is fully subjected to the collection of rocks, the jewellery of Lady Slazenger underlines her personal drama, works of art emphasise Murway's tragedy, his melancholy and disillusionment with life. All the collections are mood-creating, evoke strong emotions both in the collector's environment and in the collectors themselves (will to power, feeling of beauty, greed, eroticism and passion). Each of the collections depicted in the novel is an important biographical object, influences the turn of events, describes the psyche of the characters and the psychological act of gathering, depicts "desire and nostalgia, rescue and loss" which accompany the act of collecting. Collecting as a literary motif can be inscribed in an important research direction complementing the issue of the psychology of characters. As a result, it is essential to extract it from prose works especially when the subject of the analysis is the depiction of the characters and the authorial ability to portray them.

Translated by Łukasz Barciński

\section{Bibliography}

Bednarska-Ruszajowa K., Biblioteki i książki w pamiętnikach polskich XVIII-XX wieku. Rekonesans źródłowy, Kraków: Wydawnictwo Uniwersytetu Jagiellońskiego, 2003.

Benjamin W., "Dzieło sztuki w dobie reprodukcji technicznej" ["The work of art in the age of mechanical reproduction"], translated into Polish by J. Sikorski, in: idem, Aniot historii. Eseje, szkice, fragmenty, selection and edition by H. Orłowski, Poznań: Wydawnictwo Poznańskie, 1996. 
Biblioteki i książki w literaturze, edited by K. Bednarska-Ruszajowa, Kraków: Wydawnictwo Uniwersytetu Jagiellońskiego, 1998.

Cabanne P. Wielcy kolekcjonerzy [The Great Collectors], translated into Polish by F. Buhl, Kraków: Wydawnictwo Literackie, 1978.

Garbol M., "Motyw Księgi u Brunona Schulza," Teofil 1994, No. 1.

Kałążny J., "Motyw biblioteki w literaturze," Biblioteka 1998, No. 2.

Kowalska B., "Kolekcjoner wobec sztuki swoich czasów," in: Nowoczesność kolekcji, scientific edition by T.F. de Rosset, A. Kluczewska-Wójcik, K. Lewandowska, Toruń: Wydawnictwo Naukowe Uniwersytetu Mikołaja Kopernika, Centrum Sztuki Współczesnej "Znaki Czasu," 2010.

Morando C., "Kolekcja Rogera Caillois: pochodzenie kamieni," in: Nowoczesność kolekcji, scientific edition by T.F. de Rosset, A. Kluczewska-Wójcik, K. Lewandowska, Toruń: Wydawnictwo Naukowe Uniwersytetu Mikołaja Kopernika, Centrum Sztuki Współczesnej “Znaki Czasu," 2010.

Nagórska I., "Biblioteka w poezji polskiej," Poradnik Bibliotekarza 1994, No. 10.

Nowoczesność kolekcji, scientific edition by T.F. de Rosset, A. Kluczewska-Wójcik, K. Lewandowska, Toruń: Wydawnictwo Naukowe Uniwersytetu Mikołaja Kopernika, Centrum Sztuki Współczesnej “Znaki Czasu,” 2010.

Pilch A., Formy wyobraźni. Poeci wspótcześni przed obrazami wielkich mistrzów, Kraków: Wydawnictwo Uniwersytetu Jagiellońskiego, 2010.

Pomian K., "Kolekcjonerstwo i filozofia. Narodziny nowożytnego muzeum," in: idem, Drogi kultury europejskiej. Trzy studia, Warszawa: Wydawnictwo Instytutu Filozofii i Socjologii PAN, 1996.

Pomian K., "Słowo wstępne," in: Nowoczesność kolekcji, scientific edition by T.F. de Rosset, A. Kluczewska-Wójcik, K. Lewandowska, Toruń: Wydawnictwo Naukowe Uniwersytetu Mikołaja Kopernika, Centrum Sztuki Współczesnej “Znaki Czasu,” 2010.

Rząsa M., "Książka w Piśmie świętym i tekstach pisarzy kościelnych," in: Prace młodych bibliotekoznawców, Kraków: Polskie Towarzystwo Bibliologiczne, 1994.

Skibiński Z., "Motyw księgi w poezji Czesława Miłosza," Mazowieckie Studia Humanistyczne 1996, No. 2.

Skorupa E., "Thanatos Malczewskiego i thanatos poetów," in: eadem, Zautki literatury. Interpretacje tekstów kultury XIX i XX wieku, Kraków: Wydawnictwo Uniwersytetu Jagiellońskiego, 2015.

Stolzman M., "Wiedza o książce w dziełach literackich," Roczniki Biblioteczne 1988, Vol. 31 (1987), Vol. 1.

Strug A., Pieniądz. Powieść z obcego życia, Warszawa: “Ignis,” 1921.

Tańczuk R., Ars colligendi. Kolekcjonowanie jako forma aktywności kulturalnej, Wrocław: Wydawnictwo Uniwersytetu Wrocławskiego, 2011.

The Cultures of Collecting, edited by J. Elsner, R. Cardinal, Cambridge, Massachusetts: Harvard University Press, 1994. 